Paula C. Lopes, Thiago S. Marques, Paula S. Martin, Carla GhelerCosta, Luciano M. Verdade

\title{
14 Patterns of Leaf-litter Amphibian Diversity in a Silvicultural Landscape of Southeastern Brazil
}

\begin{abstract}
Amphibians are susceptible to environmental changes due to a combination of morphological, physiological and behavioral characteristics adapted to specific environmental conditions. Few studies focus on the patterns of amphibian diversity in disturbed habitats by human action. However, recent studies with other taxa suggest that agricultural landscapes can support considerable biodiversity. The main goal of this study was to evaluate the spatial-temporal distribution and abundance patterns of leaf-litter amphibians inhabiting a silvicultural landscape. This study was conducted at Três Lagoas and Arca farms, located in the Upper Paranapanema basin, state of São Paulo, in southeastern Brazil. The data collection was carried out from August 2007 to July 2009 in monthly sampling campaigns. A grid of sampling units ( $\mathrm{n}=30)$ formed by pitfall traps were distributed over Eucalyptus plantations $(\mathrm{n}=18)$, native vegetation ( $n=7)$ and abandoned pastures $(n=5)$. A total of 1047 leaf-litter individuals from 18 species were captured in the study area. The leaf-litter amphibian assemblage was composed predominantly by Physalaemus cuvieri (58.6\%), Physalaemus nattereri (13.1\%), and P. marmoratus (13.0\%). There was a significant difference in species richness and abundance between environments, surprisingly with the lowest species richness and abundance in the native vegetation. However, there was no relationship between species richness and relative abundance considering the distance of water bodies or the native vegetation. The results of this study suggest that silvicultural landscapes may have some conservation value. In order to improve it, it is necessary to maintain conservation areas within the landscape, as well as to stimulate innovation in silvicultural wildlife-friendly management practices.
\end{abstract}

\subsection{Introduction}

The expansion of socioeconomic activities has proven to be a major driver of the alteration and destruction of natural habitats (Rocha et al., 2006). This process caused extensive impacts on biodiversity in different regions of the world due to the replacement of native vegetation by agricultural crops and livestock areas (Diamond, 1997; Noris, 2008). These agricultural systems are spatially homogeneous (e.g. monoculture of sugarcane and Eucalyptus), but temporally heterogeneous due to the production cycle. The management of these systems may result in profound changes in the wildlife by modifying the spatial distribution of resources (Eterovick \& Sazima, 2000; Silvano et al., 2003). These processes can compromise gene flow and dispersal 
frequency resulting in population decline (Feder \& Burggren, 1992; Young et al., 2000).

The socioeconomic development of the state of São Paulo in Southeastern Brazil reflects the global trend of natural resources utilization. The economic development model adopted by the state caused profound changes in its original vegetation, gradually replaced by agroecosystems (Victor et al., 2005). Such process resulted in the current critical environmental scenario, with only $17.5 \%$ of the native vegetation remaining (IF, 2009).

The state of São Paulo has approximately 1.2 Mha covered by forest plantations that correspond to the second largest in Brazil (ABRAF, 2013). Most of this area was formerly occupied by low productivity pastures (Vianna et al., 2007). In turn, environmental laws due to the relatively well established certification process (i.e. Forest Stweardship Council - FSC) in this sector provides the implementation of Areas of Permanent Protection (APP) and Legal Reserve (LR). Such change on the landscape structure can have direct and indirect consequences on local biodiversity.

A priori, amphibians can be considered good indicators of environmental change as they generally have relatively small home range and most depend on the availability of aquatic environments for reproduction and terrestrial environments for foraging, aestivation, migration and dispersion (Stebbins \& Cohen, 1995; Zug et al., 2001; Pough et al., 2004). Habitat fragmentation, deforestation and water contamination by agrochemicals have been considered the main causes of global decline of amphibians (Gray et al., 2004; Young et al., 2004). Many species are also sensitive to changes in the vegetation structure near water bodies (Jim, 1980; Valan, 2002; Renken et al., 2004) and their dispersal patterns are intrinsically related to habitat quality (Duelman \& Trueb, 1994; Peltzer et al., 2003). However, tolerant amphibians have been recorded in anthropic environments (e.g. Demaynadier \& Hunter, 1998; Campos \& Vaz-Silva, 2010; Machado et al., 2011).

The main goal of this study was to evaluate spatial-temporal variation in diversity of leaf-litter amphibians inhabiting a silvicultural landscape during the first three years (0-3 year) of Eucalyptus plantations. The following null-hypotheses have been tested: 1) There is no difference in leaf-litter amphibians diversity among the different components of silvicultural landscapes (Eucalyptus plantations, abandoned pastures and native vegetation remnants); 2) There is no relation between leaf-litter amphibians diversity and their distance to the nearest border of native vegetation inside the matrix (Eucalyptus plantations); 3) There is no time variation in leaf-litter amphibians diversity in silvicultural landscapes; and, 4) There is no intraspecific difference in body length in leaf-litter amphibians in relation to the silvicultural landscape components. 


\subsection{Material and Methods}

\subsubsection{Study Area}

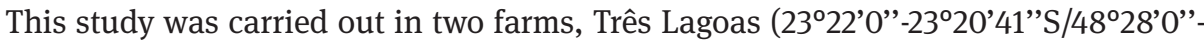

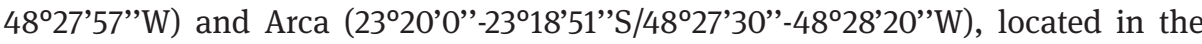
Alto Paranapanema watershed, in the state of São Paulo, in Southeastern Brazil. The regional climate is classified as subtropical (Cwa) according to the Köppen system with an average monthly temperature of $20.6^{\circ} \mathrm{C}$ (ranging from $14.1^{\circ} \mathrm{C}$ in June 2008 to $24.3^{\circ} \mathrm{C}$ in March 2009) and average monthly cumulative rain of $113 \mathrm{~mm}$ (ranging from $0 \mathrm{~mm}$ in July 2008 to $314 \mathrm{~mm}$ in January 2009) during the study period (data from Estação Experimental de Ciências Florestais de Itatinga - Escola Superior de Agricultura “Luiz de Queiroz”, Universidade de São Paulo).

The two farms together have a total area of 4333 ha (Três Lagoas: 3242 ha and Arca: 1123 ha) composed by a mosaic of Eucalyptus plantations (as the landscape matrix), fragments of native vegetation and abandoned pastures. In the past, livestock production was the major activity; however, between 2006 and 2008, much of the pastures were converted into Eucalyptus plantations. The remaining area was abandoned for natural revegetation, according to the Brazilian environmental law.

Local Eucalyptus plantations are composed by Eucalyptus grandis, E. urophila and their hybrid E. urograndis. Native vegetation is composed by fragments of Semideciduous Forest (dominated by Cariniana estrelensis, Cedrela fissilis, Coccoloba mollis, Crysophyllum marginatum, Gallesia integrifolia, Lonchocarpus muehlbergianus, Prunus sellowii and Machaerium villosum), Cerrado sensu stricto (dominated by Annona cacans, A. coriacea, Aspidosperma tomentosa, Anadenanthera falcata, Dalbergia miscolobium, Eryotheca gracilipes, Caryocar brasiliense, Dimorphandra mollis, Stryphnodendron adstringens and Ouratea spectabilis) and Cerradão (dominated by Tapirira guianensis, A. crassiflora, Xylopia brasiliensis, A. australe, Gochnatia polymorpha, Terminalia brasiliensis, Miconia chartacea, Pera glabrata, Amaioua guianenis and Vochisia tucanorum). Abandoned pastures are dominated by Brachyarya syn. Urochloa spp. (Athayde, 2013).

\subsubsection{Methodology}

\subsubsection{Sampling Methodology}

The study design is based on the methodology proposed by the Biodiversity Research Program (PPBio) where sampling units form a grid with nodules distant one kilometer from each other. This methodology is appropriate for long-term ecological research because it allows rapid biota inventories (Magnusson et al., 2005). In the present study, 30 sampling units (located in the grid nodules) were implemented taking into account the proportion of the three landscape elements: Eucalyptus plantations ( $\mathrm{n}=$ $18)$, native vegetation $(n=7)$ and abandoned pasture $(n=5)$. 
The amphibian captures were conducted with drift fence pitfall traps (Corn, 1994; Block et al., 1998; Cechin \& Martins, 2000; Dixo \& Verdade, 2006; Bernarde \& Macedo, 2008). Each sample unit was composed by four $100 \mathrm{~L}$ buckets buried to the surface of the ground connected by guide fence (plastic net) with $80 \mathrm{~cm}$ high (10 cm buried) in shape of "Y" with $15 \mathrm{~m}$ long segments. Buckets had small holes for rainwater drainage and remained capped while not in use. Small mammal studies were also carried out simultaneously (Martin et al., 2012; Rosalino et al., 2013).

Data collection occurred in 23 monthly campaigns from August 2007 to July 2009 (skipping November 2008 due to logistical impediments). The buckets remained open for two consecutive nights in each campaign and were checked every morning. Captured animals were identified, measured (body length), sexed and released at the capture site. Vouchers of amphibian species were deposited in the collection "Célio F. B. Haddad” (CFBH) of Instituto de Biociências - Universidade Estadual Paulista - Campus Rio Claro, under appropriate license from the Instituto Chico Mendes de Conservação da Biodiversidade - ICMBio (License n 12623-1 and 12623-2). Species identification followed the Brazilian Society of Herpetology (Segalla et al., 2012).

\subsubsection{Analytical Methodology}

The sampling effort sufficiency to characterize the leaf-litter amphibian diversity was evaluated for each landscape unit and for the whole study area by species incidence curves (adapted from Colwell \& Coddington, 1994) where the time-series sigmoid model bootstrapped (1000 randomizations by EstimateS software - Colwell, 2004) asymptote was considered the estimated number of species. The sampling effort (SE) of pitfall traps methodology was calculated according to the formula:

$$
S E=C \times D \times U \times P F
$$

where $C$ is the number of sampling campaigns, $D$ the number of sampling days, $U$ the number of sampling units and $P F$ the number of pit-fall stations. The capture success $(C S)$ was calculated according to the formula:

$$
C S=(T / S E) \times 100
$$

where $T$ is the total number of individuals captured and $S E$ is the sampling effort. Abundance index (AI) was calculated according to the formula:

$$
A B=T / S E \text {. }
$$

Prior to statistical analysis we tested data distribution and homoscedasticity, respectively by Anderson-Darling and Levene's tests. One-way analysis of variance (ANOVA) (Zar, 2010) and Kruskal-Wallis test (Siegel, 1956) were used to respectively test whether leaf-litter amphibian species richness and relative abundance differ among the three distinct landscape units (Eucalyptus plantations, abandoned pastures and native vegetation). Analysis of means (ANOM) (Ott, 1983) was then applied as a post-hoc test. In addition, Correspondence Analysis (Manly, 1994) was used to verify the possible relation between the landscape unit type and species composition (Hypothesis 1). Linear regressions (Zar, 2010) were used to detect the 
possible relationship between species richness and relative abundance of leaf-litter amphibians and the distance of the sampling units to the nearest water body and native vegetation using 14 sampling units located within Eucalyptus plantations of Três Lagoas Farm (Hypothesis 2).

The temporal variation in species richness and overall relative abundance was evaluated by t-test (Zar, 2010) and Mann-Whitney test (Siegel, 1956), respectively (Hypothesis 3). April through September was considered dry season whereas October through March was considered wet season. In addition, temporal variation along this study period is presented. At last, one-way ANOVA (Zar, 2010) were applied to check possible differences in snout-vent length (SVL) of dominant species among environments (Hypothesis 4). All analyzes were performed in the statistical software Minitab 16.

\subsection{Results}

Eighteen leaf-litter amphibian species were detected in the study area, totaling 1047 captured individuals. These species are distributed in the families Bufonidae, Craugastoridae, Cycloramphidae, Leiuperidae, Leptodactylidae and Microhylidae (Tab. 14.1). The total sampling effort was 4977 trap-night (Eucalyptus plantations = 3054 trap-night; native vegetation $=1030$ trap-night; abandoned pasture $=893$ trapnight) and the overall capture success was $21.05 \%$. Our sampling effort was enough to detect from 83.3 to $93.5 \%$ of the estimated leaf-litter amphibian species richness of this study area (Fig. 14.1, Tab. 14.2).

No species detected in this study is considered threatened or endangered according to the IUCN Red List (IUCN, 2014) and the List of Endangered Fauna of the State of São Paulo (State Decree No. 60.133/2014). The leaf-litter amphibian assemblage in our study area is composed predominantly by Physalaemus cuvieri (58.6\%), Physalaemus nattereri (13.1\%) and Physalaemus marmoratus (13.0\%). There was a significant difference in species richness and relative abundance of leaf-litter amphibians among environments (richness: $\mathrm{F}_{2,29}=7.20 ; \mathrm{p}=0.003$; abundance: $\mathrm{H}_{2,29}=$ 11.89; $\mathrm{p}=0.003$ ), with the lowest species richness and abundance surprisingly in the native vegetation (Fig. 14.2). In addition, there appears to be a consistent difference between native vegetation and anthropic environments (i.e. Eucalyptus plantations and abandoned pasture) in terms of amphibian diversity (i.e. species composition, richness and relative abundance - Fig. 14.3 and 14.4). We can thus reject the first null hypothesis. However, there was no clear relationship between species richness and relative abundance of leaf-litter amphibians both to the distance from nearest water bodies (richness: $\mathrm{F}_{1,13}=0.71 ; \mathrm{p}=0.414 ; \mathrm{r}^{2}=5.6$; relative abundance: $\mathrm{F}_{1,13}=0.77, \mathrm{p}=$ $0.397 ; r^{2}=6.1$ ) or the nearest native vegetation border (richness: $F_{1,13}=0.12 ; p=0.733 ; r^{2}$ $=1.0$; relative abundance: $F_{1,13}=0.23 ; p=0.644 ; r^{2}=1.8$; Fig. 14.5). Therefore, we cannot reject the second null hypothesis. 
Tab. 14.1: Number of individuals of leaf-litter amphibians on a silvicultural landscape of Angatuba, state of São Paulo, Southeastern Brazil.

\begin{tabular}{|c|c|c|c|c|}
\hline Family/Species & $\begin{array}{l}\text { Eucalyptus } \\
\text { Plantations }\end{array}$ & $\begin{array}{l}\text { Native } \\
\text { Vegetation }\end{array}$ & $\begin{array}{l}\text { Abandoned } \\
\text { Pasture }\end{array}$ & Total \\
\hline \multicolumn{5}{|l|}{ Bufonidae } \\
\hline Rhinella ornata & 1 & 5 & 0 & 6 \\
\hline R. schneideri & 3 & 0 & 0 & 3 \\
\hline \multicolumn{5}{|l|}{ Craugastoridae } \\
\hline Haddadus binotatus & 0 & 5 & 3 & 8 \\
\hline \multicolumn{5}{|l|}{ Cycloramphidae } \\
\hline Odontophrynus americanus & 7 & 1 & 0 & 8 \\
\hline \multicolumn{5}{|l|}{ Leiuperidae } \\
\hline Physalaemus centralis & 35 & 2 & 3 & 40 \\
\hline P. cuvieri & 200 & 41 & 373 & 614 \\
\hline P. nattereri & 80 & 4 & 54 & 138 \\
\hline P. marmoratus & 122 & 0 & 15 & 137 \\
\hline P. olfersii & 0 & 1 & 0 & 1 \\
\hline \multicolumn{5}{|l|}{ Leptodactylidae } \\
\hline Leptodactylus cf. furnarius & 0 & 1 & 0 & 1 \\
\hline L. fuscus & 40 & 1 & 7 & 48 \\
\hline L. labyrinthicus & 0 & 1 & 1 & 2 \\
\hline L. latrans & 4 & 0 & 1 & 5 \\
\hline L. mystaceus & 0 & 1 & 0 & 1 \\
\hline L. mystacinus & 5 & 0 & 3 & 8 \\
\hline \multicolumn{5}{|l|}{ Microhylidae } \\
\hline Chiasmocleis albopunctata & 2 & 0 & 0 & 2 \\
\hline Elachistocleis cf. bicolor & 2 & 0 & 2 & 4 \\
\hline E. cf. ovalis & 9 & 0 & 12 & 21 \\
\hline Total & 510 & 63 & 474 & 1047 \\
\hline
\end{tabular}




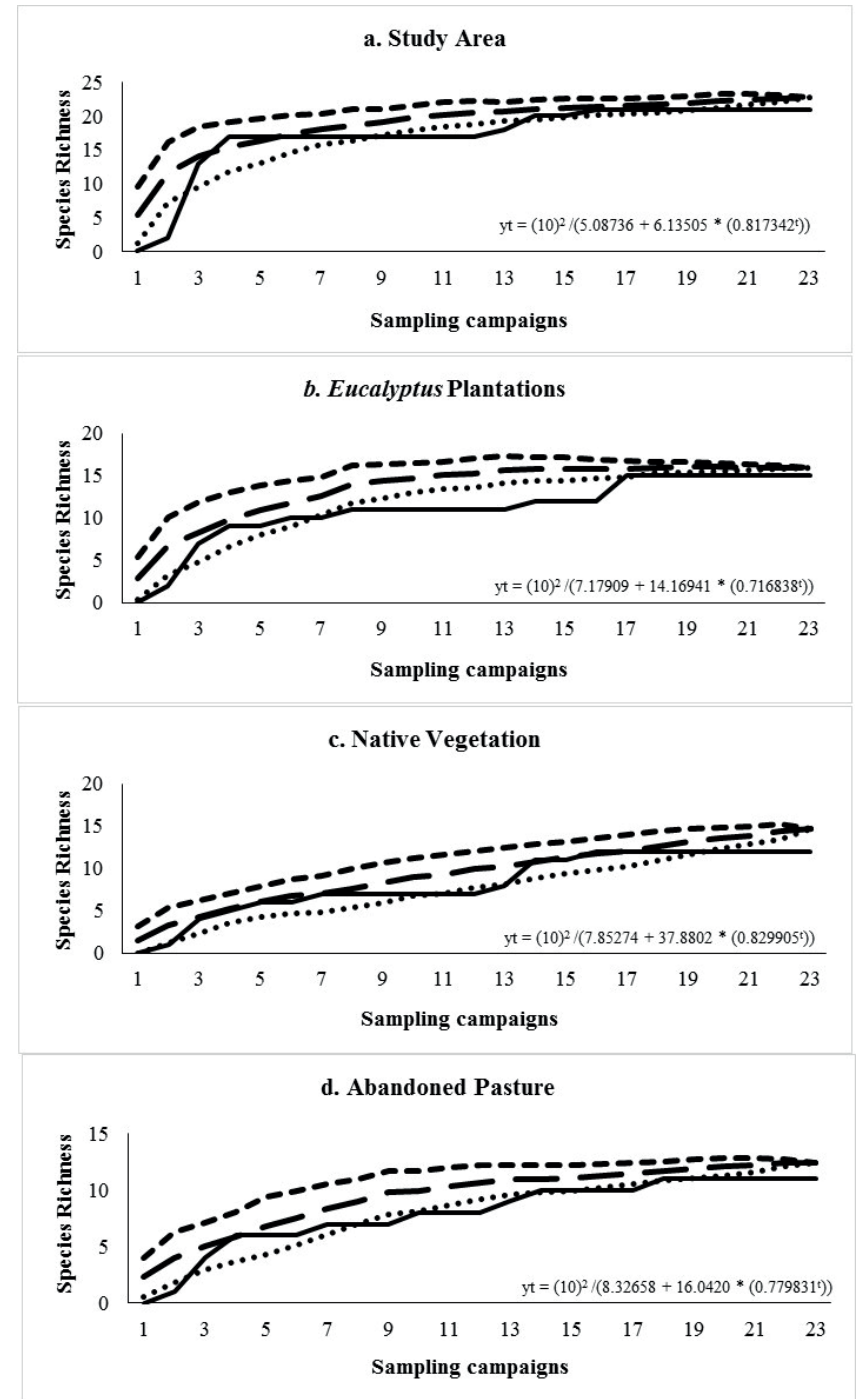

Fig. 14.1: Leaf-litter amphibians' species incidence curves, for the whole landscape and its environments.

Tab. 14.2: Estimated $\left(r_{\text {est }}\right)$ and detected $\left(r_{\text {det }}\right)$ species richness of leaf-litter amphibians on a silvicultural landscape of Angatuba, state of São Paulo, Southeastern Brazil.

\begin{tabular}{llll}
\hline Environment & $r_{\text {est }}$ & $r_{\text {det }}$ & $\left(r_{\text {det }} / r_{\text {est }}\right) \times 100(\%)$ \\
\hline Eucalyptus plantation & 13.9 & 13 & 93.5 \\
Abandoned pasture & 12.7 & 11 & 86.6 \\
Native vegetation & 12 & 10 & 83.3 \\
Total & 19.7 & 18 & 91.3 \\
\hline
\end{tabular}



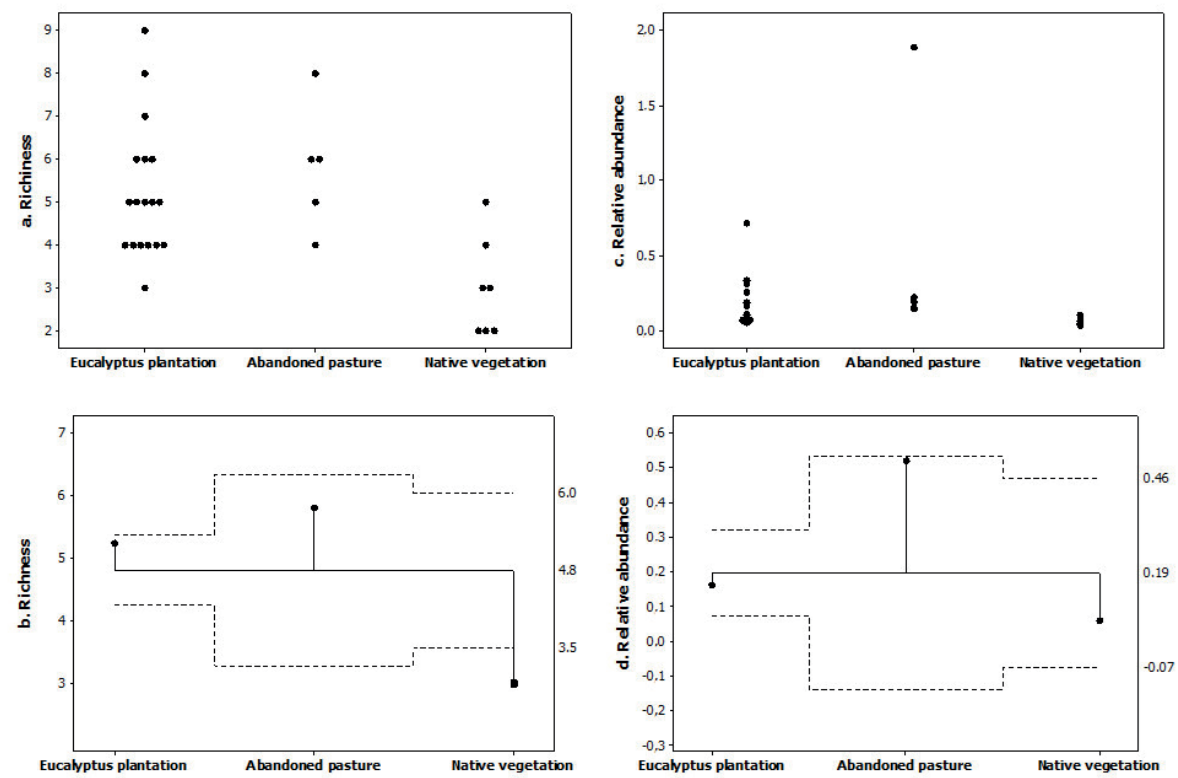

Fig. 14.2: Species richness and relative abundance of leaf-litter amphibians in a silvicultural landscape in Angatuba, state of São Paulo, Southeastern Brazil. In "A" and " $C$ ” black dots represent the collected data. In "B" and "D" mean and standard deviation are presented in the Analysis of Means.

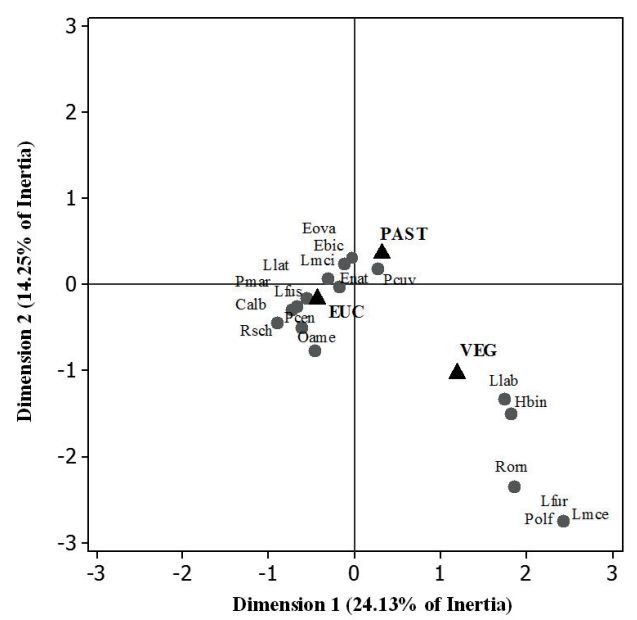

Fig. 14.3: Correspondence Analysis plot, relating the landscape unit types and species composition and relative abundance. EUC: Eucalyptus plantation, PAST: Abandoned pasture and VEG: Native vegetation. Calb - Chiasmocleis albopunctata, Ebic - Elachistocleis cf. bicolor, Eova - E. cf. ovalis, Hbin - Haddadus binotatus, Lfur - Leptodactylus cf. furnarius, Lfus - Leptodactylus fuscus, Llab - L. labyrinthicus, Llat - L. latrans, Lmci - L. mystacinus, Lmce - L. mystaceus, Oame - Odontophrynus americanus, Pcen - Physalaemus centralis, Pcuv - P. cuvieri, Pmar - P. marmoratus, Pnat Physalaemus nattereri, Polf - P. olfersii, Rorn - Rhinella ornata and Rsch - R. schnederi. 


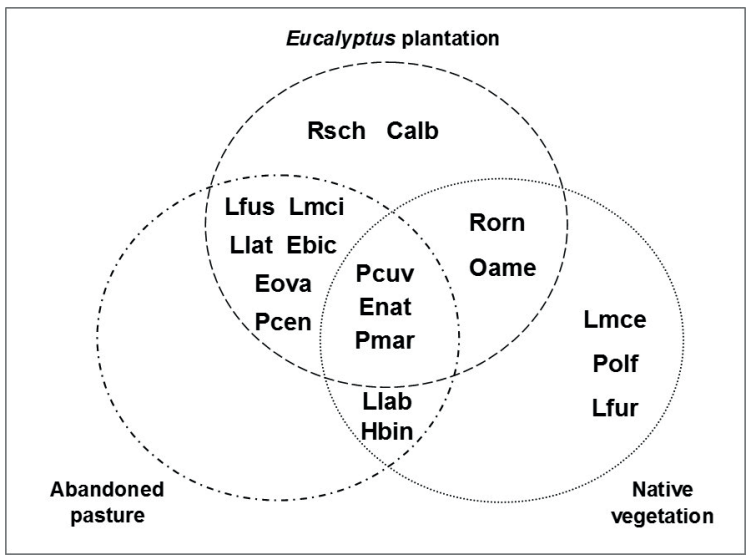

Fig. 14.4: Composition of leaf-litter amphibians by environment in a silvicultural landscape in Angatuba, state of São Paulo, Southeastern Brazil (Calb - Chiasmocleis albopunctata, Ebic Elachistocleis cf. bicolor, Eova - E. cf. ovalis, Hbin - Haddadus binotatus, Lfur - Leptodactylus cf. furnarius, Lfus - Leptodactylus fuscus, Llab - L. labyrinthicus, Llat - L. latrans, Lmci - L. mystacinus, Lmce - L. mystaceus, Oame - Odontophrynus americanus, Pcen - Physalaemus centralis, Pcuv - P. cuvieri, Pmar - P. marmoratus, Pnat - Physalaemus nattereri, Polf - P. olfersii, Rorn - Rhinella ornata and Rsch - R. schnederi).
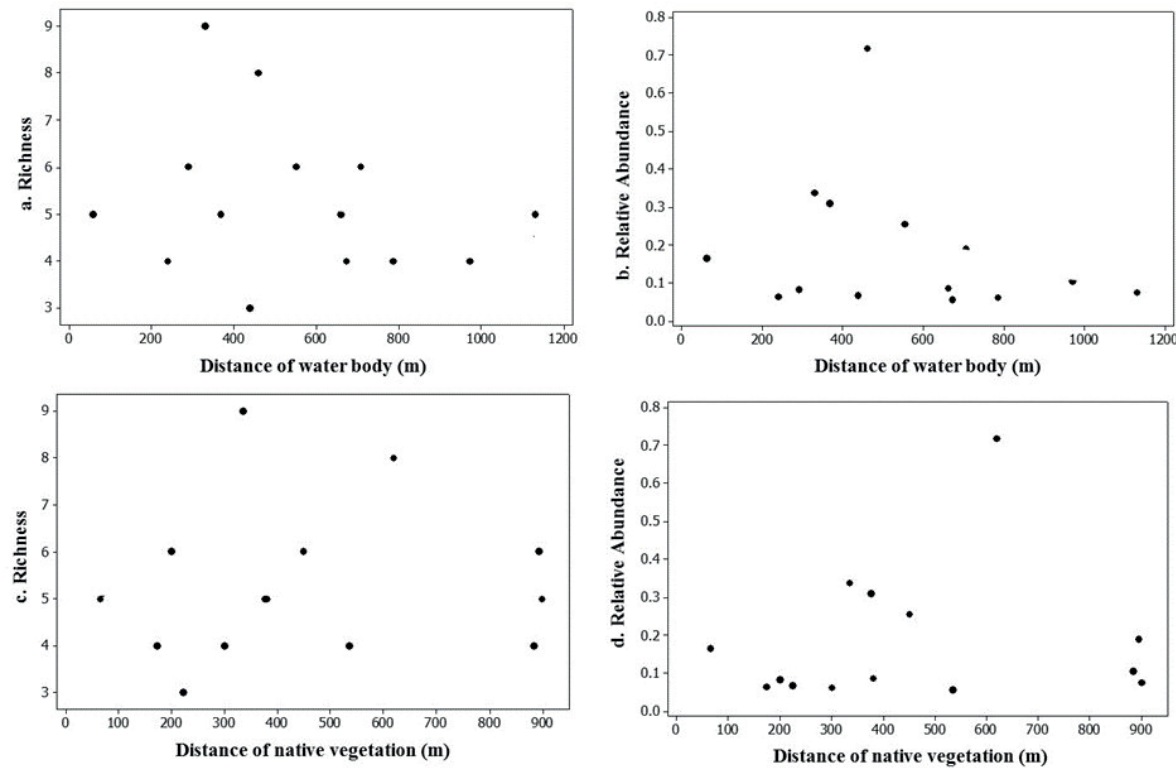

Fig. 14.5: Relationship between richness and relative abundance of litter amphibians and distance from nearest water body and native vegetation. 
The species richness and overall relative abundance varied significantly between the dry and wet seasons sampled (richness: $\mathrm{t}_{1,22}=2.99 ; \mathrm{p}=0.007$; relative abundance: $\mathrm{W}_{1,22}=93.0 ; \mathrm{p}=0.001$ ), both higher in the wet season. In addition, there appears to be a consistent time variation along the study period in terms of leaf-litter amphibians in all landscape components (Fig. 14.6). We can, therefore, reject the third null hypothesis.
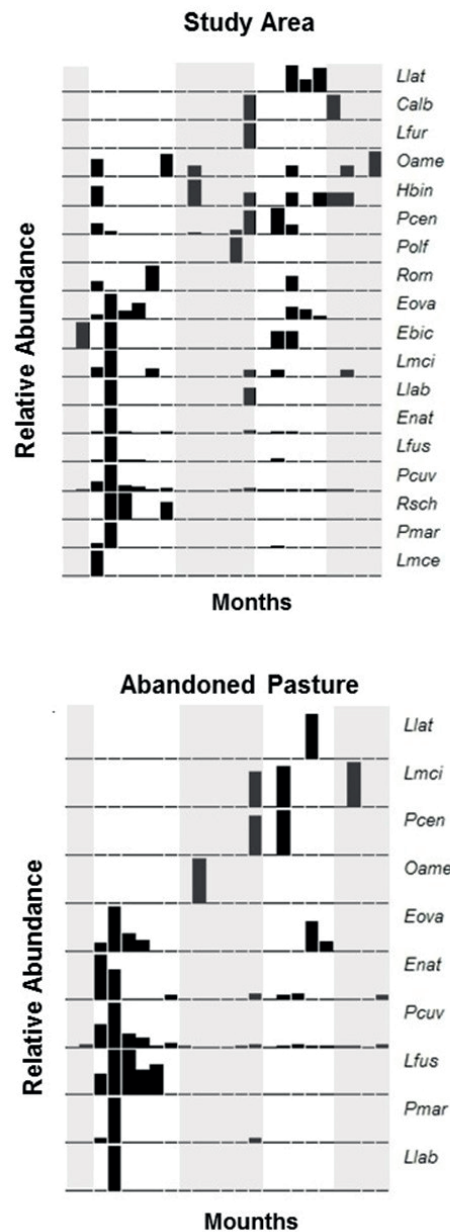
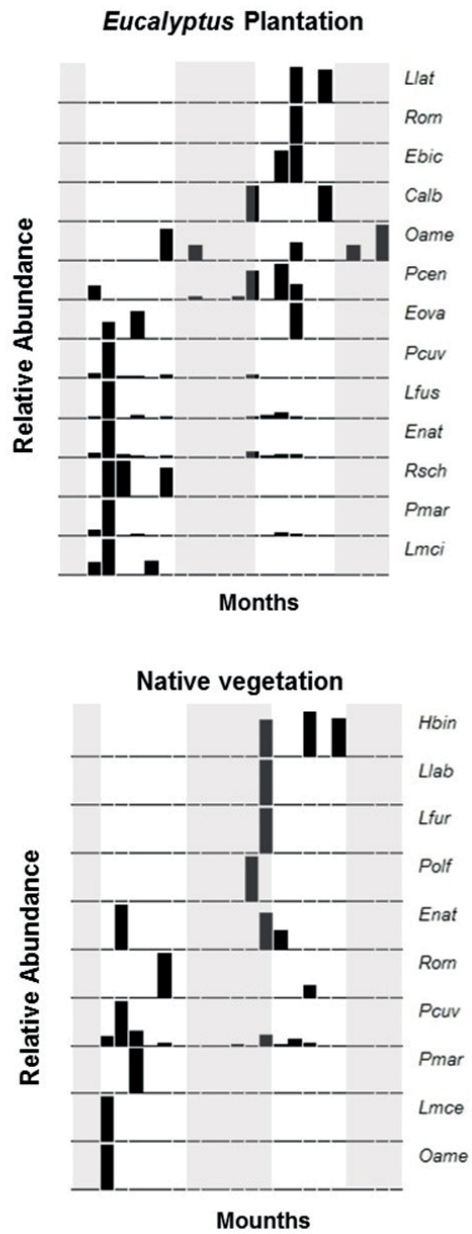

Fig. 14.6: Temporal variation in the relative abundance of the different litter amphibians species detected in the study area (Calb - Chiasmocleis albopunctata, Ebic - Elachistocleis cf. bicolor, Eova - E. cf. ovalis, Hbin - Haddadus binotatus, Lfur - Leptodactylus cf. furnarius, Lfus - Leptodactylus fuscus, Llab - L. labyrinthicus, Llat - L. latrans, Lmci - L. mystacinus, Lmce - L. mystaceus, Oame Odontophrynus americanus, Pcen - Physalaemus centralis, Pcuv - P. cuvieri, Pmar - P. marmoratus, Pnat - Physalaemus nattereri, Polf - P. olfersii, Rorn - Rhinella ornata and Rsch - $R$. schnederi). The area shaded in gray represents dry season and the area without shadow represents wet season. 
The dominant species, $P$. marmoratus and $P$. nattereri, showed no intraspecific differences in snout-vent length in relation to the environments (P. marmoratus: $\mathrm{F}_{1,53}=$ 1.75; $\mathrm{p}=0.191 ;$ Eucalyptus plantation $=3.6 \pm 0.5 \mathrm{~cm}$; abandoned pasture $=4.0 \pm 0.4 \mathrm{~cm}$; P. nattereri: $\mathrm{F}_{2,104}=1.01 ; \mathrm{p}=0.367$; Eucalyptus plantation $=4.2 \pm 0.5 \mathrm{~cm}$; native vegetation $=4.2 \pm 0.2 \mathrm{~cm}$; abandoned pasture $=4.3 \pm 0.6 \mathrm{~cm})$. However, there was a significant difference for P. cuvieri, with snout-vent length slightly longer in Eucalyptus plantations, but shorter in smaller at abandoned pastures $\left(\mathrm{F}_{2,235}=8.85 ; \mathrm{p}<0.001\right.$; Eucalyptus plantation $=2.7 \pm 0.6 \mathrm{~cm}$; native vegetation $=2.7 \pm 0.2 \mathrm{~cm}$; abandoned pasture $=2.4 \pm$ $0.6 \mathrm{~cm}$ ) (Fig. 14.7). We can, therefore, partially reject the fourth null hypothesis.

\section{Physalaemus cuvieri}

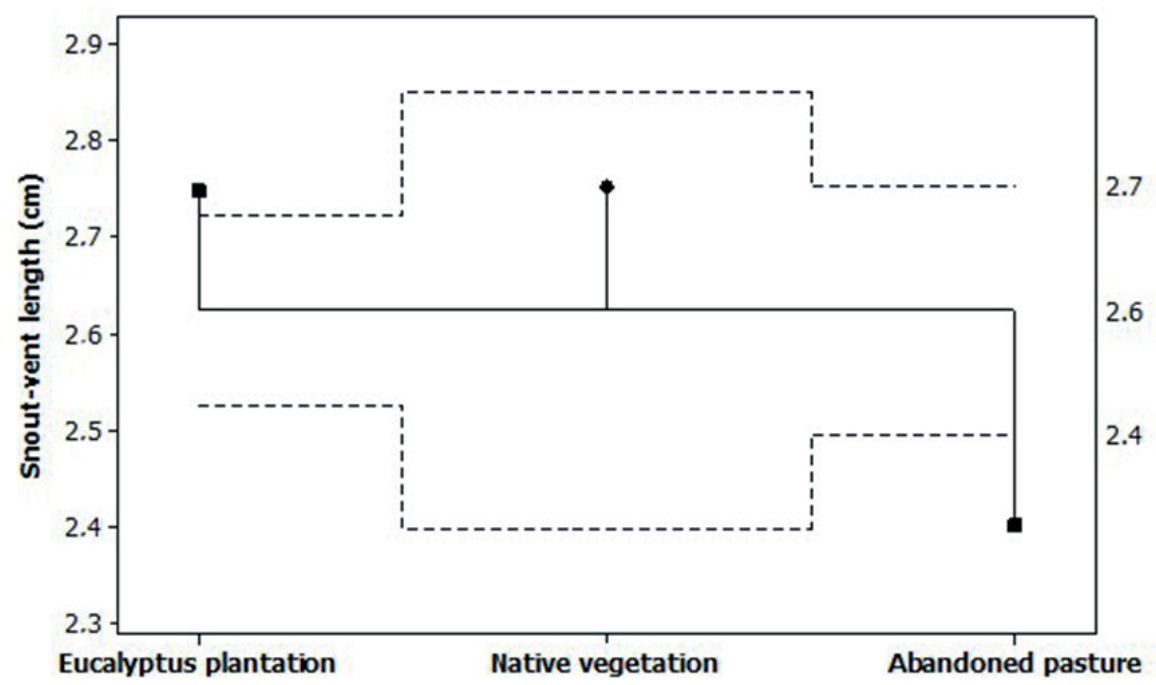

Fig. 14.7: Intraspecific variation of snout-vent length of leaf-litter amphibians in different components of a silvicultural landscape in Angatuba, state of São Paulo, Southeastern Brazil.

\subsection{Discussion}

Although we carried out monthly sampling campaigns during two years the number of species detected in each sampled environment (from 83.3 to 93.5\%) suggest that more intense sampling effort (possibly longer than only 2 night captures per month) should be applied in silvicultural landscapes. However, for logistic reasons, in order to do so it might be necessary to restrict the number of sampling units per sampled environment. Future studies should prioritize sampling design and sampling 
methodology concerning leaf-litter amphibians in silvicultural (and agricultural) landscapes. Such concerns have been raised for mammals (Lyra-Jorge et al., 2014) and birds (Penteado et al., 2014) as traditional methods for vertebrate surveys have been generally developed for pristine environments from temperate regions (Sutherland, 2006).

The pattern of variation in species richness and relative abundance of leaf-litter amphibians among environments found in this study is possibly due to the expansion of the dominant species in anthropic areas at the beginning of the Eucalyptus cycle (first three years of implantation), possibly in response to the sudden increase in food supply and lack of predators. This hypothesis is corroborated when we reanalyze the data without the dominant species with consequently no difference in species richness and relative abundance among environments (richness: $F_{2,29}=2.02 ; p=0.153$; abundance: $\mathrm{H}_{2,29}=2.34 ; \mathrm{p}=0.311$ ). The conversion of pasture on Eucalypts plantations promotes the appearance of an arboreal extract, an increase on the litter amount, a decrease in soil compaction and a decrease in light incidence (Alves et al., 2006). Such factors can be beneficial to some species of amphibians. Future studies should investigate whether such patterns persist along the productive cycles of the Eucalypus plantations (i.e. during a few decades).

The species composition of leaf-litter amphibians appears to be different between the native vegetation and the anthropic environments, with no distinction in this study between Eucalyptus plantations and abandoned pastures. Such patterns could be due to the fact that the initial phase of Eucalyptus plantations has structural characteristics intermediate between open and forest environment. In such a circumstance, Cerrado species like Physalaemus cuvieri, P. centralis, P. marmoratus and Physalaemus nattereri can be benefitted (Bastos, 2007).

Surprisingly, native vegetation showed just few exclusive species in relation to the anthropic environments. This pattern may be the historical result of local land use and exploitation of natural resources (e.g. deforestation). The study area is located in a transition between Cerrado and Semideciduous forest that suffered cycles of deforestation and revegetation since 1870 (Lisboa, 2008). Since the early 1970's, land use has been dominated by pastures for livestock production which possibly resulted in local extinction of many forest species of leaf-litter amphibians. Different species may be distinctly affected by land use changes (Swihart et al., 2003; Rubbo \& Kiezecker, 2005). Revegetation of conservation areas (i.e. APP and LR) might result in an increase in leaf-litter amphibian diversity. A network of long-term biodiversity monitoring sites should be established in agricultural/silvicultural landscapes in order to evaluate the impacts of changes on land use and agricultural management practices on biodiversity (Verdade et al., 2014a) including leaf-litter amphibians.

The distance from water bodies or native vegetation can be decisive for amphibian survival. However, no such pattern has been detected in this study, which can be partially explained by the presence of small fragments of native vegetation of irregular shape with relatively small species richness possibly due to border 
effect (i.e., increase in temperature and decrease in relative humidity). In addition, in this study we considered only permanent water bodies due to the logistical difficulties to monitor temporary water bodies in large areas long term. However, the distribution of temporary water bodies may have affected the present results, since most leptodactylids of the Physalaemus group use temporary ponds and puddles for reproduction (Brasileiro et al., 2005). Such temporary water bodies can increase the carrying capacity of Eucalyptus plantations for leaf-litter amphibian at least in the early phase of its first productive cycle.

The species richness and overall relative abundance varied between dry and wet seasons. The decrease in abundance during the dry season may be related to lower activity of amphibians during this period due to decrease in temperature, humidity conditions and food supply (Gibbs, 1998; Alford \& Richards, 1999; Pinheiro et al., 2002; Vasconcelos \& Rosa-Feres, 2005). Humidity and/or temperature have been considered the main determining factors of amphibian diversity (Aichinger, 1987; Maffei et al., 2011). Most amphibian species which inhabit regions without marked seasonality can reproduce throughout the year; however, Cerrado species tend to concentrate their reproductive activities during rainy season (Brasileiro et al., 2005) as they depend on temporary aquatic environments to breed (Duellman \& Trueb, 1986). The temporal distribution of the species in this study seems to be consistent with this pattern.

Body size is related to age, gender, phylogeny, and environment (Calder, 1996; Morrison \& Hero, 2003; Bidau et al., 2011). Habitat-related body-size variation can be an important indicator of a species' ability to adapt and survive to environmental change (Rosalino et al., 2013). As an example, the reduction in blacksnake head size has been associated with the consumption of smaller prey (Phillips \& Shine, 2004). The relationship between snout-vent length and the environment found in this study for $P$. cuvieri may be due to a possible increase in environmental quality from the abandoned pasture to the native vegetation and the Eucalyptus plantation. However, this pattern can possibly be affected by silvicultural management practices like chemical weed control and mechanical harvest. Future studies should investigate the availability of food resources in the distinct environments of silvicultural landscapes along productive cycles of Eucalyptus plantations.

The results of this study suggest that silvicultural landscapes may have some conservation value, as long as natural water bodies are maintained along with conservation areas (i.e. APP/LR). In addition, the development of wildlife-friendly silvicultural management practices (i.e. the maintenance of sparse native trees inside Eucalyptus plantations and a relaxation in chemical weed control, as suggested by Athayde (2013) and Millan (2013), might possibly increase $\beta$-diversity in silvicultural landscapes (Verdade et al., 2014b). Such information should be incorporated in the certification process of Eucalyptus production (e.g. Forest Stewardship Council) in order to improve the conservation value of silvicultural landscapes. 
Acknowledgements: This study was funded by the Biota Program/FAPESP (Proc. 2006/60954-4) and Ripasa S.A. Papel e Celulose. Paula C. Lopes and Thiago S. Marques had scholarships from FAPESP (Procs. 2007/01632-0 and Procs. 2013/110320 , respectivelly). Luciano M. Verdade hold a CNPq Productivity Scholarship (309468/2011-6).

\section{Bibliography}

ABRAF (2012). Anuário estatístico da ABRAF 2012, ano base 2011. Retrieved from: http://www. abraflor.org.br/estatisticas/ABRAF12/ABRAF12-BR.pdf. Access on: 30 Jan. 2014.

Aichinger, M. (1987). Annual activity patterns of anurans in a seasonal neotropical environment. Oecologia, 71, 583-592.

Alford, R.A., \& Richards, S.J. (1999). Global amphibian declines: a problem in applied ecology. Annual Review of Ecology and Systematics, 30, 133-165.

Athayde, E.A. (2013). Importância da heterogeneidade natural na conservação da diversidade de árvores em paisagem agrosilvicultural. Thesis in Biological Sciences. Universidade Estadual Paulista „Júlio de Mesquita Filho”, Rio Claro, SP.

Alves, M.V.G., Koehler, H.S., \& Mello Filho, B. (2006). Tendências e perspectivas para o setor florestal brasileiro. Retrieved from: http://www.iufro.org/ uploads/media/t1-alves-marcosdiag-for-br.pdf. Access on: 09 Mar. 2007.

Bastos, R.P. (2007). Anfíbios do Cerrado. In L. B. Nascimento \& M. E. Oliveira (Eds.), Herpetologia no Brasil II (pp. 87-100). Belo Horizonte: Sociedade Brasileira de Herpetologia.

Bernarde, P.S., \& Macedo, L.C. (2008). Impacto do desmatamento e formação de pastagens sobre a anurofauna de serapilheira em Rondônia. Iheringia, 98, 454-459.

Bidau, C.J., Martí, D.A., \& Baldo, D. (2011). Inter- and Intraspecific Geographic Variation of Body Size in South American Redbelly Toads of the Genus Melanophryniscus Gallardo, 1961 (Anura: Bufonidae). Journal of Herpetology, 45, 66-74.

Block, M.B., Morrison, M.L., \& Scott, P.E. (1998). Development and evaluation of habitat models for herpetofauna and small mammals. Forest Science, 44, 430-437.

Brasileiro, C.A., Sawaya, R.J., Kiefer, M.C., \& Martins, M. (2005). Amphibians of an open Cerrado fragment in southeastern Brazil. Biota Neotropica, 5, 1-17.

Calder, W.A. (1996). Size, Function and Life History. Mineola, NY: Dover Publications Inc.

Campos, F.S., \& Vaz-Silva, W. (2010). Distribuição espacial e temporal da anurofauna em diferentes ambientes no município de Hidrolândia, GO, Brasil Central. Neotropical Biology and Conservation, 5, 179-187.

Cechin, S.Z., \& Martins, M. (2000). Eficiência de armadilhas de queda (pitfall traps) em amostragens de anfíbios e répteis no Brasil. Revista Brasileira de Zoologia, 17, 729-740.

Colwell, R.K. (2004). EstimateS: statistical estimation of species richness and shared species from samples. Retrieved from: http://viceroy.eeb.uconn.edu/estimates/EstimateSPages/ EstSUsersGuide/EstimateSUsersGuide.htm. Access on: 10 Jan. 2013.

Colwell, R.K., \& Coddington, J.A. (1994). Estimating terrestrial biodiversity through extrapolation. Philosophical Transaction of the Royal Society of London, 345, 101-118.

Corn, P.S. (1994). Straight-line drift fences and pitfall traps. In W.R. Heyer, M.A. Donnely, R. W. Mcdiarmid, L.C. Hayek \& M.S. Foster (Eds.), Measuring and monitoring biological diversity: standard methods for amphibians (p.109-117). Washington, DC: Smithsonian Institution.

Demaynadier, P.G., \& Hunter Jr., M.L. (1998). Effects of silvicultural edges on the distribution and abundance of amphibians in Maine. Conservation Biology, 12, 340-352. 
Diamond, J. (1997). Armas, germes e aço: os destinos das sociedades humanas. Rio de Janeiro, RJ: Record.

Dixo, M.B.O., \& Verdade, V.K. (2006). Herpetofauna de serrapilheira da Reserva Florestal de Morro Grande, Cotia (SP). Biota Neotropica, 6, 1-20.

Duellman, W.E., \& Trueb, L. (1994). Biology of amphibians. New York, NY: McGraw-Hill Publishing.

Eterovic, P.C., \& Sazima, I. (2000). Structure of an anuram community in a montane meadow in southeastern Brazil: effects of seasonality, habitat and predation. Amphibia-Reptilia, 21, 439-461.

Feder, M.E., \& Burggren, W.W. (1992). Environmental physiology of the amphibians. Chicago: The University of Chicago Press.

Gibbs, J.P. (1998). Amphibian movements in response to forest edges, roads, and streambeds in Southern New England. Journal of Wildlife Management, 62, 584-589.

Gray, M.J., Smith, L.M., \& Brenes, R. (2004). Effects of agricultural cultivation on demographics of southern high plains amphibians. Conservation Biology, 18, 1368-1377.

I.F. (Instituto Florestal do Estado de São Paulo) (2009). Inventário florestal da vegetação nativa do estado de São Paulo. Retrieved from: http://www.iflorestal.sp.gov.br/imagindex/ mapainventario.pdf. Access on: 10 Jan. 2013.

IUCN (2014). The IUCN Red List of Threatened Species. Version 2014.1. Retrieved from: http://www. iucnredlist.org. Access on: 12 Jun. 2014.

Jim, J. (1980). Aspectos ecológicos dos anfíbios registrados na região de Botucatu, São Paulo (Amphibia, Anura). Thesis in Zoology, Universidade de São Paulo, São Paulo, SP.

Lisboa, M.A.M. (2008). A política dos coronéis e a difusão do ensino primário em Angatuba/SP (1870-1930). Thesis in Education, Universidade Estadual de Campinas, Campinas, SP.

Lyra-Jorge, M.C., Gheler-Costa, C., Piña, C.I., Rosalino, L.M., \& Verdade, L.M. (2014). Wildlife Surveys in Agricultural Landscapes: Terrestrial Medium- to Large-Sized Mammals. In L.M. Verdade, M.C. Lyra-Jorge, \& C.I. Piña (Eds.), Applied Ecology and Human Dimensions in Biological Conservation (p.133-147). EUA: Springer-Verlag Berlin Heidelberg.

Machado, L.M., Mathias, P.V.C., Oliveira Jr., J.M.B., Sousa, P.C.F., \& Calvão, L.B. (2011). 0 impacto de uma monocultura de eucalipto sobre a comunidade de anfíbios (anuros) no município de Luziânia-GO, Brasil. Enciclopédia Biosfera, 7, 1-16.

Maffei, F., Ubaid, F.K., \& Jim, J. (2011). Anurofauna em área de cerrado aberto no município de Borebi, estado de São Paulo, Sudeste do Brasil: uso do habitat, abundância e variação sazonal. Biota Neotropica, 11, 221-233.

Magnusson, W.E., Lima, A.P., Luizão, R., Luizão, F., Costa, F.R.C., Castilho, C.V., \& Kinupp, V.F. (2005). RAPELD: a modification of the Gentry method for biodiversity surveys in long term ecological research sites. Biota Neotropica, 5, 1-6.

Manly, B.F.J. (1994). Multivariate statistical methods: a primer. London: Chapman \& Hall Statistics Texts.

Martin, P.S., Gheler-Costa, C., Lopes, P.C., Rosalino, L.M., \& Verdade, L.M. (2012). Terrestrial non-volant small mammals in agro-silvicultural landscapes of Southeastern Brazil. Forest Ecology and Management, 282, 185-195.

Millan, C.H. (2013). Influência de práticas de manejo e contexto da paisagem sobre a ocorrência de aves em plantio exótico de eucalipto. Master in Ecology, University of São Paulo, São Paulo, SP.

Morrison, C., \& Hero, J.M. (2003). Geographic variation in life-history characteristics of amphibians: a review. Journal of Animal Ecology, 72, 270-279.

Noris, K. (2008). Agriculture and biodiversity conservation: opportunity knocks. Conservation Letters, 1, 2-11.

Ott, E.R. (1983). Analysis of means: a graphical procedure. Journal of Quality Technology, 15, 10-18. 
Peltzer, P.M., Lajmanovich, R.C., \& Beltzer, A.H. (2003). The effects of habitat fragmentation on amphibian species richness in the floodplain of the middle Parana River. Herpetological Journal, 13, 95-98.

Penteado, M., Silva, W.R., \& Verdade, L.M. (2014). Point counts method for bird surveys in agroecosystems of the State of São Paulo, southeastern Brazil. In L.M. Verdade, M.C. Lyra-Jorge, \& C.I. Piña (Eds.), Applied Ecology and Human Dimensions in Biological Conservation (p.149-158). EUA: Springer-Verlag Berlin Heidelberg.

Phillips, B.L., \& Shine, R. (2004). Adapting to an invasive species: toxic cane toads induce morphological change in Australian snakes. PNAS, 101, 17150-17155.

Pinheiro, F., Diniz, I.R., Coelho, D., \& Bandeira, M.P.S. (2002). Seasonal pattern of insect abundance in the Brazilian cerrado. Austral Ecology, 27, 132-136.

Pough, F.H., Andrews, R.M., Cadle, J.E., Crump, M.L., Savitzky, A.H., \& Wells, K.D. (2004). Herpetology. New Jersey, NJ: Pearson Prentice Hall.

Renken, R.B., Wendy, K.G., Debra, K.F., Stephen, C.R., Timothy, J.M., Kevin, B.R., Bradley, R., \& Wang, X. (2004). Effects of forest management on amphibians and reptiles in Missouri Ozark Forests. Conservation Biology, 18, 174-188.

Rocha, C.F.D., Bergallo, H.G., Sluys, M.V., \& Alves, M.A.S. (2006). Biologia da conservação: Essências. São Carlos, SP: Rima Editora.

Rosalino, L.M., Martin, P.S., Gheler-Costa, C., Lopes, P.C., \& Verdade, L.M. (2013). Allometric relations of neotropical small rodents (Sigmodontinae) in anthropogenic environments. Zoological Science, 30, 585-590.

Rubbo, M.J., \& Kiezecker, J.M. (2005). Amphibian breeding distribution in an urbanized landscape. Conservation Biology, 19, 504-511.

Segalla, M.V., Caramaschi, U., Cruz, C.A.G., Garcia, P.C.A., Grant, T., Haddad, C.F.B., \& Langone, J. (2012). Brazilian amphibians - List of species. Sociedade Brasileira de Herpetologia. Retrieved from: http://www.sbherpetologia.org.br. Access on: 30 Jan. 2014.

Siegel, S. (1956). Nonparametric statistics for the behavioral sciences. New York, NY: McGraw Hill Publishing.

Silvano, D.L., Colli, G.R., Dixo, M.B.O., Pimenta, B.V.S., \& Wiederhecker, H.C. (2003). Anfíbios e Répteis. In D.M. Rambaldi \& D.A.S. Oliveira (Eds.), Fragmentação de Ecossistemas: causas, efeitos sobre a biodiversidade e recomendações de políticas públicas (p.183-200). Brasília: Ministério do Meio Ambiente/Secretaria de Biodiversidade e Florestas.

Stebbins, R.C., \& Cohen, N.W. (1995). A Natural History of Amphibians. New Jersey, NJ: Princeton University Press.

Sutherland, W.J. (2006). Ecological Census Techniques - A Handbook. Cambridge, UK: Cambridge University Press.

Swihart, R.K., Gehring, T.M., Kolozsvary, M.B., \& Nupp, T.E. (2003). Responses of "resistant” vertebrates to habitat loss and fragmentation: the importance of niche breadth and range boundaries. Diversity and Distributions, 9, 1-18.

Valan, D. (2002). Effects of anthropogenic environmental changes on amphibian diversity in the rain forests of eastern Madagascar. Journal of Tropical Ecology, 18, 725-742.

Vasconcelos, T.S., \& Rossa-Feres, D.C. (2005). Diversidade, distribuição espacial e temporal de anfíbios anuros (Amphibia, Anura) na região noroeste do Estado de São Paulo, Brasil. Biota Neotropica, 5, 1-14.

Verdade, L.M., Penteado, M., Gheler-Costa, C., Dotta, G., Rosalino, L.M., Pivello, V.R., \& Lyra-Jorge, M. C. (2014a). The conservation value of agricultural landscapes. In L.M. Verdade, M.C. Lyra-Jorge \& C.I. Piña (Eds.), Applied Ecology and Human Dimensions in Biological Conservation (p.91-103). EUA: Springer-Verlag Berlin Heidelberg. 
Verdade, L. M., Lyra-Jorge, M.C., \& Piña, C.I. (2014b). Redirections in conservation biology. In L.M. Verdade, M.C. Lyra-Jorge \& C.I. Piña (Eds.), Applied Ecology and Human Dimensions in Biological Conservation (p.3-17). EUA: Springer-Verlag Berlin Heidelberg.

Vianna, L.G.G., Sato, A.M., Fernandes, M.C., \& Netto, A.L.C. (2007). Fronteira de expansão dos plantios de eucalipto no geoecossistema do médio vale do rio Paraíba do Sul (SP/RJ). In Seminário de recursos hídricos da bacia hidrográfica do Paraíba do Sul: O Eucalipto E O Ciclo Hidrológico. Taubaté: IPABHI.

Victor, M.A.M., Cavalli, A.C., Guillaumon, J.R., \& Serra-Filho, R. (2005). Cem anos de devastação revisitada 30 anos depois. Brasília: Ministério do Meio Ambiente/ Secretaria de Biodiversidade e Florestas.

Young, B.E., Lips, K.R., Reaser, J.K., et al. (2000). Population declines and priorities for amphibian conservation in Latin America. Conservation Biology, 15, 1213-1223.

Young, B.E., Stuart, S.N., Chanson, J.S., Cox, N.A., \& Boucher, T.M. (2004). Joyas que estan desapareciendo: El estado de los anfibios en el Nuevo Mundo. Arlington, VA: NatureServe.

Zar, J.H. (1996). Biostatistical analysis. Upper Saddle River: Prentice Hall.

Zug, G.R., Vitt, L.J., \& Caldwell, J.P. (2001). Herpetology: an introductory biology of amphibians and reptiles. San Diego, CA: Academic Press. 